\title{
Open Economies, Insider Power and International Migration
}

\author{
George M Agiomirgianakis
}

\begin{abstract}
In this paper we incorporate the possibility of international migration of Labour (IML) into a model of open economy with a non-competitive labour market. Migration flows in our model are endogenously determined by labour market performance. Our approach to the specification of the labour market is based on a trade union model where employed workers can exercise insider power. The model we develop allows for a simultaneous determination of union membership and real wages under conditions of migration outflows.

In this framework, we show that migration outflows, lead to a real consumer wage higher than what would have been in the absence of migration. We also show that an increase in the rest-of-the-world wage or a decrease in the average migration cost will lead to higher real consumer wages at home. On the other hand, an increase in the real exchange rate will increase the home real product wage, however, the sign of change in the home real consumer wage is ambiguous. Finally, an improvement in the firm's product market will raise both the domestic real consumer wage and the employment level.
\end{abstract}

JEL Classification: J42, F22.

Key words: Migration, Open Economy, Labour Economics.

\section{ADDRESS FOR CORRESPONDENCE}

Dr. George M. Agiomirgianakis

Department of Economics

City University

School of Social Sciences

Northampton Square

London EC1V OHB

Tel 0171-477-8591, Fax: 0171-477-8580

Email: G.M.Agios@city.ac.uk

URL:http://www.city.ac.uk/economics/george.html

\footnotetext{
\# I am grateful to Emmanuel Petrakis for valuable comments and helpful suggestions. Thanks are also due to an anonymous referee for constructive comments and the participants of the conferences: "Medium-Long Term Dynamics of Industrial Employment in OECD Countries" financed by the National Research Council of Italy, CNR, Bologna University, Italy, 26-28 May, 1997 and the Annual Conference of the European Association of Labour Economists, Aarhus, Denmark, 25-28 Sept. 1997, for useful suggestions and comments on an earlier version of the paper. Financial support from CNR is gratefully acknowledged. Of course, any shortcomings of the paper are my own responsibility.
} 


\section{Introduction}

Much of the theoretical literature on international migration of labour (IML) assumes competitive labour markets. The labour markets of most countries, however, do not conform with this assumption: many western countries are currently experiencing a persistently high level of unemployment; and changes in the marginal revenue product of labour are usually accompanied by changes in the level of employment rather than in real wages. These two stylised facts of today's economies, unemployment and real wage rigidity, should in principle be taken into account in examining the macroeconomic implications of international migration of labour. Few exceptions to full employment treatment of international migration, are the papers by Bhagwati \& Hamada (1974), McCulloch \& Yellen (1975), Rodriguez (1976), Djajic (1985) and Schmidt (1994). These papers, however, assume either a non market-clearing wage that is set administratively (by, for example, minimum wage legislation) or treat migration flows as exogenous (bounded by government regulations).

Contemporary economic theory suggests three approaches to unemployment and rigid wages that differ from the traditional consideration of minimum wage legislation. The first is the "implicit contracts" theory, which assumes that firms supply their workers with insurance against income uncertainty. This results in a relatively stable real wage. The second is the "trade union" model, which is based on the assumption that trade unions have some bargaining power over wages and/or employment. The third approach is the "efficiency wages" theory, which assumes that labour effort is related to real wages offered by firms. To date, no attempt has been made in the literature to incorporate the possibility of IML into these three models of unemployment.

The aim of this paper is to incorporate the possibility of IML into a trade union model of a small open economy with a flexible exchange rate. In the context of our model, international migration flows are endogenously related to the labour market performance rather than fixed by government regulations. Our motivation comes from Brecher \& Choudhri (1987) who argue that IML will cause a partial adjustment in the wage rate even if this wage rate is set unilaterally by a trade union or by a firm through efficiency wage considerations. Furthermore, the choice of a trade union approach rather than an efficiency wage approach is based on two considerations. First, as Nickell (1990) notes, "we have some evidence in favour of the efficiency wage story but it is not, as yet, overwhelming". Second, trade unions play a decisive role in wage-employment decisions in many industrial countries, 
particularly in Europe (see, e.g. Layard, Nickell \& Jackman, (1991,1994) and Lindbeck (1993)).

We will restrict our analysis to the case of a small open economy, which faces outflows of labour (emigration). We will also assume that the economy is made up of many identical firms, all unionised. This assumption allows us to consider the wage-employment bargaining within an individual firm as a microcosm of the entire labour market wage-employment bargaining. Throughout the paper we shall further assume that the union is concerned only with the welfare of its existing members and wishes to maximise the expected utility of its median member. In Section 2 we extend the efficient bargains model to the open-economy case. In this model the union and the firm bargain over the joint determination of the wage rate and the level of employment. The outcome of this bargaining is Pareto efficient, i.e. it lies on the contract curve. In Section 3 we open up the economy to international migration. The decision to migrate or not is assumed to be based on the existing wage differential between the small open economy and the rest of the world. In this context, migration outflows reduce the membership of the trade union. Since the union is concerned with the welfare of its existing members, lower membership results in higher wages, as there are fewer union jobs to be protected. Hence employment and union membership remain lower after the migration flows have ceased and unemployment may be lower or unchanged depending on whether or not "outsiders" are migrating. We also find that, through international migration, the home real consumer wage is positively related to the rest-of-theworld wage and negatively related to average migration cost: an increase in the rest-of-theworld wage or a decrease in the migration cost induces a larger proportion of insiders to migrate abroad. Therefore, the smaller number of remaining insiders, acting through their union, will succeed in achieving higher real consumer wages at home. On the other hand, an increase in the real exchange rate increases the home real product wage. However, the sign of change in the home real consumer wage is ambiguous. Finally, an improvement in the firm's product market by strengthening the bargaining position of the trade union leads to an increase in both the real consumer wage and the employment level.

Section 4 contains concluding comments. 


\section{The Efficient Bargains Model of Trade Unions in the an Open Economy Case}

We consider an open economy that is made up of many identical firms, all unionised. Thus, the wage-employment activity within an individual firm may be seen as a microcosm of the wage-employment activity of the entire labour market.

Trade unions theory is based on the idea that unions are concerned only with the welfare of their existing members and aim to maximise an objective function. The specification, however, of the union's objective may take a variety of functional forms. Following Layard, Nickell \& Jackman (1991) we shall assume here that the union wishes to maximise the expected utility of its median voter derived from the real consumer wage.

We may, then, specify the union's objective function as

$$
V=\left[u\left(\omega^{c}\right)-u\left(\chi^{c}\right)\right] \min \left(\frac{L}{L_{o}}, 1\right)
$$

Where

$u\left(\omega^{c)} \quad\right.$ is the utility of the median voter derived from the real consumer wage, net of the disutility of work

$u\left(\chi^{c}\right) \quad$ is the utility derived from not working

$\omega^{c} \equiv \frac{W}{P_{c}} \quad$ be the real consumer wage

W

is the money wage

$P_{c}$

is the consumer price index defined as $P_{c}=P^{\lambda}\left(E P^{*}\right)^{1-\lambda}$

$\mathrm{P}$

is the GDP deflator

$P^{*}$

is the foreign price level

E is the nominal exchange rate (defined as units of domestic currency per unit of foreign currency)

$\lambda$ is the share of domestic goods in total domestic consumption. The assumption that $\lambda>0.5$ means that home residents have a preference for home goods.

$\chi^{c} \equiv \frac{X}{p_{c}} \quad$ be the real consumption layoff pay; which is the income equivalent of not being employed. is the money layoff pay 
$\mathrm{L} \quad$ is employment

$L_{o} \quad$ is the initial membership of the union (taken to be exogenous)

$\frac{L}{L_{O}} \quad$ is the probability of the median voter to be employed, for $L \leq L_{O}$

Next we turn our analysis to the firm's objective. We formalise the firm's objective in a conventional way: we assume that the firm is concerned with the real producer profit. Let $f(L)$ be a strictly concave production function. Then, real profits are given by

$$
\pi=f(L)-\omega^{p} L
$$

Where

$\omega^{p} \equiv \frac{W}{P} \quad$ be the real producer wage.

Having analysed the objectives of the firm and the union, we now turn our analysis to the determination of the wage rate and the level of employment. For this purpose we need to specify the process (bargaining structure) by which the firm and the union reach agreement. We shall consider the case of the efficient bargains, that is, the union and the firm may bargain over the joint determination of the wage rate and the level of employment. Bargains of this type are off the labour demand curve and are Pareto efficient. Efficient bargains or efficient contracts are points of tangency between a union's indifference curve and an isoprofit curve. The set of efficient bargains is the contract curve of the barter between the union and the firm.

To arrive at some determinate point on the contract curve, we need an explicit bargaining theory. The best known formal solution to the bargaining problem is the Nash bargaining solution. Following Creedy \& McDonald (1991) we will assume here different bargaining powers for the union and the firm. Thus the asymmetric Nash bargaining solution maximises the weighted geometric mean (Nash product or Nash maximand) of the union's and firm's payoffs. Hence, the Nash product to be maximised is

$$
N=\left\{\frac{L}{L_{o}}\left[u\left(\omega^{c}\right)-u\left(\chi^{c}\right)\right]\right\}^{\frac{\phi}{1+\phi}}\left[f(L)-\omega^{p} L\right]^{\frac{1}{1+\phi}}
$$

where the weights $\frac{\phi}{1+\phi}$ and $\frac{1}{1+\phi}$ are the bargaining powers of the union and the firm respectively. 
Differentiation of (3) with respect to $w$ and L gives the first-order conditions:

$$
\widetilde{\varepsilon}=\frac{\omega^{p}}{\omega^{p}-f^{\prime}(.)} \quad(\text { contract }- \text { curve })
$$

and

$$
\omega^{p}=\frac{\phi}{1+\phi}\left[\frac{\phi f(L)}{L}+f^{\prime}(L)\right] \quad(\text { power locus })
$$

where

$\widetilde{\varepsilon} \equiv \frac{\omega^{c} u^{\prime}\left(\omega^{c}\right)}{u\left(\omega^{c}\right)-u\left(\chi^{c}\right)}$ is the real consumer wage elasticity of net utility from work.

The above can be best explained in terms of Figure $1^{1}$. The indifference curves in the $\left(\omega^{p}, L\right)$ space are "kinked". They are rectangular hyperbolas, asymptotic to $\omega=\chi$ for $L \leq L_{O}$, while for $L>L_{O}$ they are horizontal. In other words, when employment is less than the union membership, the union is prepared to trade wages for employment. On the other hand, when employment exceeds the union membership, the union places no value on further employment since the median member is always employed and he is then only concerned with his wage.

The family of isoprofit curves in the $\left(\omega^{p}, L\right)$ space is also depicted in Figure 1. Each isoprofit curve is concave from below. The locus of the maximum points of the isoprofit curves is the labour demand curve, since the labour demand curve defines the profit-maximising employment at any wage. Hence, isoprofit curves are upward sloping to the left of the labour demand curve and downward sloping to the right of the labour demand schedule. A lower isoprofit curve is more desirable for the firm since it represents higher profits: for any given L, a smaller W implies an increase in firm's profits.

Equation (4) defines the contract curve of efficient bargains. This result is not surprising since the derivation of Nash solution uses Pareto optimality as one of its axioms ${ }^{2}$. The contract curve is depicted in Figure 1 by the upward sloping curve from A to B. Equation (5) is the "power locus" $(P L)$. Given the concavity of the production function, both the average and the marginal product of labour are decreasing. As a result, $P L$ is negatively sloped as illustrated in Figure 1. The $P L$ starts from point $\mathrm{C}$, which lies on the isoprofit curve of zero profits and on the labour demand curve.

\footnotetext{
1 We adopt here the diagrammatic exposition used by Creedy and McDonald (1991).

${ }^{2}$ See also Fallon and Very (1988) p.186.
} 
The intersection of the upward sloping contract curve and the downward sloping power locus determines the bargained wage. Substituting (5) into (4) one can get an algebraic expression for the bargained wage $W^{*}$, given by the condition

$$
\widetilde{\varepsilon} \equiv \frac{\phi+\alpha}{\phi(1-\alpha)}
$$

Equation (6) states that the bargained wage is a mark-up on the layoff pay $\chi^{c}$, in terms of utility.

\section{Efficient Bargains, Insider Power and International Migration}

In our analysis so far we have examined the efficient bargains model in the case of a closed and an open economy but we have ignored the possibility of international migration. In this section we open up the economy to international migration and we consider the efficient bargains model in a dynamic context.

As Bhagwati \& Rodriguez (1983, p.209) note, international migration in a dynamic context can be analysed either as a once-and-for-all labour movement or as a rate of migration per unit of time. Here, for simplicity, we shall treat IML as a once-and-for-all labour movement. Moreover, following Layard, Nickell \& Jackman (1991), we shall start our analysis by considering the economy in an initial period where no labour outflows occur and an efficient bargains' real wage has been established. Then, we shall move on to the next period where migration outflows will be assumed to take place and we shall examine their implications for real wages and employment. More specifically, we shall consider two periods of time, period 1 and period 2. In period 1, no migration outflows take place and the labour market is described by our analysis in Section 2. In period 2, which is analysed in this section, a once- and-for-all migration outflow occurs and we examine its implications for the bargained real wage and the employment level. This simplified assumption of two periods will allow us to distinguish between the two situations, i.e. no migration and migration. It may be justified on the grounds that an economy first establishes its wages and employment level, for any given international economic conditions, and then any changes in the international economic conditions are taken into account.

Since in this section we open up the economy to international migration, we need to consider first how a migration outflow will affect the bargaining between the two players, i.e. the firm and the union. To simplify the analysis we shall make the assumption that only 
employed workers are migrating ${ }^{3}$. As will become evident shortly, because the bargained wage is determined solely by the behaviour of employed workers, whether or not the unemployed workers migrate abroad has no impact on the bargained wage.

For the firm a migration outflow will mean a lower number of employees, while for the union it will mean lower membership. At an unchanged bargained wage, lower employment will mean a lower wage bill and thus higher profits for the firm. In terms of Figure 1, this is illustrated by a move to a lower isoprofit curve. On the other hand, lower union membership will, at an unchanged bargained wage, increase the probability of the median member to be employed. Thus if the union is to remain on the same indifference curve the real bargained wage has to increase. Therefore, a migration outflow will be in favour of the firm and against the union. How will the union react to this situation? Will the union bargain for higher wages or/and higher employment? To answer these questions, we need to extend the efficient bargains model to the case where the membership of the union is not fixed. The best known approach to a changing union membership is the "insiders-outsiders model". ${ }^{4}$

The insider-outsider approach was developed in a series of contributions by Lindbeck \& Snower (1986, 1987), Blanchard \& Summers (1986), Carruth \& Oswald (1987), Gottfries \& Horn (1987), Blanchard \& Fischer (1989), Drazen \& Gottfries (1990) and Layard, Nickell \& Jackman (1991). Following the insider-outsider theory we distinguish between two types of workers: the employed trade union members, the "insiders"; and the unemployed nonunion members, the "outsiders". An insider who loses his job is assumed to leave the union and to become an outsider. As a result, the trade union reflects the interest of the insiders to the detriment of the outsiders. Outsiders have no role in the bargaining process, since they are assumed not to be able to undercut employed workers. This assumption is a crucial one and is based on the existence of labour turnover costs. That is, the basic idea is that it will be costly for a firm to exchange employed union members (insiders) for unemployed union members (outsiders) because of firing and hiring costs. These labour turnover costs place a market power into the hands of the insiders, which they may exploit for their own interests, i.e. to push up their wages or to maintain their jobs. Furthermore, by reflecting the interests

\footnotetext{
${ }^{3}$ Hazari (1994), in a framework of skilled and unskilled labour, assumes that only skilled and employed workers emigrate. In our framework the insider status guarantees, both, employment and the right to use one's skills, while an outsider is de-franchised from both.

${ }^{4}$ The extension of the efficient bargains model into the case of insider power is quite natural since, as Layard, Nickell \& Jackman, (1991), pp.27-28 note "Any union model of unemployment is (and always has been) a model of insider power."
} 
of the currently employed workers, the union will attach no importance to creating employment for the currently unemployed. In other words, the union's indifference curves will be kinked at an employment level equal to its current membership. Indeed, as Carlin and Soskice (1990, p. 449) argue, the objectives of the insiders are

"(1) to maintain their own employment; (2) to increase their real wage, with objective (1) taking precedence over (2); and (3) to attach no importance to creating employment for those who are currently unemployed...”

Let us assume that in period 1 the intersection of the contract curve with the power locus determines the bargained real product wage and the employment level, i.e. the point $\left(\omega_{1}^{p^{*}}, L_{1}{ }^{*}\right)$. Since the initial membership of the union was $L_{o}$, the number of unemployed union members in period 1 is given by the difference $L_{o}-L_{1} *$. We may now move on to period 2 and ask what will happen to union membership in this period.

Following the insiders-outsiders theory and assuming first that no migration outflows take place, union membership will be $L_{1} *$. This means that the union's indifference curves will now be kinked at the employment (membership) level $L_{1}{ }^{*}$ and not at $L_{O}$. This is illustrated in Figure 2, where the zone of horizontal parts of the indifference curves is extended leftwards to $L_{1} *$. That is, for $L>L_{1}{ }^{*}$, the union reflecting the interests of the insiders will not be prepared to bear any sacrifice in wages in return for a higher level of employment. Let $E$ denote the point with coordinates $\left(\omega_{1}{ }^{p^{*}}, L_{1} *\right)$. Since the indifference curves are kinked at $L=L_{1} *$ and are negatively sloping for $L<L_{1} *$, the new contract curve will be positively sloped for $L<L_{1} *$ and vertical at $L=L_{1} *$. This is depicted in Figure 2, where the new contract curve is shown by the kinked curve AEH.

We turn next our attention to the power locus. The slope and the shape of the PL is unaffected by the position of the point where the indifference curves are kinked. However, the effective part of the power locus is now CE since the union is not prepared to trade wages for employment beyond $L_{1} *$ The intersection of the two loci will occur at point $E$ where $\omega_{2}{ }^{p}=\omega_{1}{ }^{*}$ and $L_{2}=L_{1} *$. That is, the bargained real wage and the level of employment will be the same as in period 1, although the union membership is lower than in period 1. The reason for this is that union membership requires workers to remain employed. Therefore, 
the insiders of period 1, acting through their union, will bargain for a wage in period 2 such that they will not lose their insider status, i.e. maintain their jobs.

Consider, next, the case where a migration outflow of workers occurs in period 2. What are the predictions of the efficient bargains model? What will be the bargained wage and the level of employment when firms and unions operate under conditions of international labour migration? As we have already explained at the beginning of this section, at an unchanged real wage, migration outflows will be against the welfare of the union. Therefore, the trade union has to take into account migration outflows when it bargains for real wages and employment with the firm. This, however, gives rise to the question of how migration outflows are determined and whether they are treated by the union as exogenously or are endogenously determined as the outcome of the bargain.

The case of exogenous labour outflows, in the form of a fixed quit rate per period of time, has been examined by Layard, Nickell \& Jackman (1991). In their analysis, they show that the remaining insiders will achieve a higher real bargained wage. In our analysis here we shall treat international migration as endogenously determined rather than as a fixed exogenous outflow of labour, unrelated to the existing conditions in the domestic labour market. Therefore, we shall extend the analysis of the efficient bargains to the case of an endogenously induced outflow of labour. At this point, we make three assumptions: first, that migration outflows depend upon the bargained real wage; second, the trade union knows the size of migration outflows that may result at each level of the bargained real wage; and third, the trade union takes into account migration outflows when it bargains with the firm over real wages and employment.

Next we need to examine the behaviour of the insiders who are potential migrants. We shall assume that the decision to migrate or not is based on the existing real consumer wage differentials between the home country and the rest of the world. ${ }^{5}$ Let $\mu$ denote a once-and-for-all fixed real migration cost. ${ }^{6}$ Most of the literature on international migration, including McCulloch \& Yellen (1975), Baldwin \& Venables (1994), and Burda (1993)), assumes that the migration cost is fixed and the same for all migrants. However, as pointed

\footnotetext{
5 A common assumption of the existing literature on labour migration is that wage differentials between countries generate international labour migration. See, for example, various papers in the May 1983 special issue of the Journal of International Economics on International Factor Mobility, as well as, Rodriguez (1976), Djajic (1985), Greenwood \& McDowell (1986), Stark (1991), Straubhaar \& Zimmermann (1992), Burda (1993) and Agiomirgianakis (1998). This assumption can be traced back to Hicks (1932), who note that "..differences in net economic advantages, chiefly differences in wages, are the main causes of migration..".
} 
out by the literature on search models with learning and migration, ${ }^{7}$ the migration cost, $\mu$, may be viewed not merely as the transportation cost, but also as a cost affected by a variety of factors, such as language and cultural differences and the existence of friends and relatives who have migrated earlier. These factors, by limiting the flow of information for some people or providing access to more information for some others, will affect $\mu$ differently across workers. ${ }^{8}$ Therefore, we shall assume that $\mu$ is fixed for each individual but varies among migrants and that it is uniformly distributed in the interval $(\mathrm{o}, \bar{\mu})$, where $\bar{\mu}$ is the highest migration cost ${ }^{9}$. This assumption, which is commonly used in industrial organisation; ${ }^{10}$ allows us to take account of the heterogeneity of the population concerning migration decisions.

Let $\omega^{f}$ be the real consumer wage in the rest of the world, which, when converted in units of domestic good, is ${ }^{11}$

$$
\bar{\omega}=\omega^{f} S^{\lambda}
$$

where $S$ is the real exchange rate.

The existing wage differential in period 2 between the home country and the rest of the world is $\bar{\omega}-\omega_{2}^{c}$.

An insider will be indifferent between migrating abroad or staying home if ${ }^{12}$

$$
\bar{\omega}-\omega_{2}^{c}=\mu
$$

\footnotetext{
6 The migration cost, $\mu$, can be treated as amortised cost, i.e. annual payments equivalent to the total lump-sum cost of emigration. See McCulloch \& Yellen (1975).

7 See Johnson \& Salt (1990) and Molho (1986) for a survey.

8 This derivation of migration function also allows us to derive a linear form of migration function.

9 See Carrington Et Al (1996) for an excellent analysis of migration with endogenous moving costs.

10 See, e.g. Tirole (1988) and Booth \& Chatterji (1993).

11 Note that the foreign real consumption wage in home currency purchasing-power units, $\bar{\omega}$, can be expressed as:
}

$$
\bar{\omega}=\frac{\omega^{f} \mathrm{P}_{\mathrm{c}}^{*} E}{P_{c}}
$$

where: $\omega^{f}$ is the foreign real consumer wage in foreign-currency purchasing power units; $P_{c}^{*}$ is the foreign real consumer prices in foreign-currency purchasing power units and $\mathrm{S} \equiv \frac{E P^{*}}{P}$ is the real exchange rate.

Using the definition of $P_{c}$ and normalising $P_{c}^{*}$ and $\mathrm{P}^{*}$ to unity we have $\bar{\omega}=\omega^{f} S^{\lambda}$.

${ }^{12}$ We have made the assumption of risk neutral workers in order to simplify our analysis. This assumption is commonly used in the international migration literature (see, for example, Bhagwati \& Hamada (1974) and McCulloch \& Yellen (1975). The case of a risk aversion utility will complicate our analysis without changing qualitatively our results. 
Let $\mu^{*}\left(\omega_{2}^{c}\right)$ be the value of the migration cost corresponding to the marginal migrant. Then, an insider who has a migrating cost lower than $\mu^{*}\left(\omega_{2}^{c}\right)$ will migrate while an insider with a migrating cost higher than $\mu^{*}\left(\omega_{2}^{c}\right)$ will stay in the home country. We may illustrate this by using the uniform distribution:

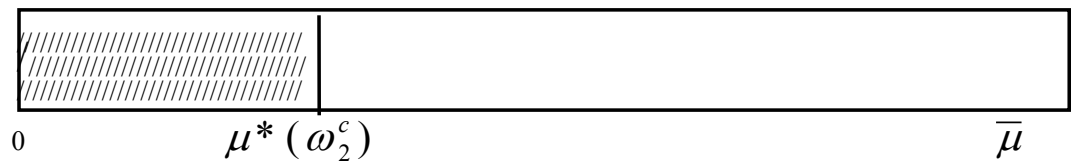

Figure 3

The whole area of the rectangle represents union membership in period 1 (insiders), which is split up by the migration cost $\mu *\left(\omega_{2}^{c}\right)$. The number of migrants is given by the number of workers whose migration cost is in the interval $\left[o, \mu *\left(\omega_{2}^{c}\right)\right)$, shown by the shadowed rectangular area in Figure 3. The remaining part of the rectangle shows the number of non-migrating insiders and hence the effective membership of the union in period 2. Therefore, the outflow of workers in period 2 is given by

$$
\frac{\mu^{*}(.)}{\bar{\mu}} L_{1}^{*}=\frac{\left(\bar{\omega}-\omega_{2}^{c}\right)}{\bar{\mu}} L_{1}^{*}
$$

\section{The union}

As we have assumed earlier, the union of insiders takes into account migration outflows when it bargains with the firm. Therefore, in period 2, the union's effective membership ${ }^{13}$ denoted by $\mathrm{M}_{2}{ }^{\mathrm{e}}$, will be

$$
M_{2}^{e}=L_{1}^{*}-\frac{\left(\bar{\omega}-\omega_{2}^{c}\right)}{\bar{\mu}} L_{1}^{*}=L_{1}^{*}\left(1-\frac{\bar{\omega}-\omega_{2}^{c}}{\bar{\mu}}\right)
$$

Obviously

$M_{2}^{e}=L_{1}^{*}$ as long as $\bar{\omega}=\omega_{2}^{c}$ and $\quad M_{2}^{e}<L_{1}^{*}$ as long as $0<\omega-\omega_{2}^{c}<\bar{\mu}$.

That is, in the absence of a real wage differential between the home country and the rest of the world, the effective union membership will be equal to the first period's

13 This can be seen as a membership demand. See Booth \& Chatterji (1993) for a similar derivation but in a framework that ignores insider power and migration. 
employment level. In the presence of wage differentials, however, the effective membership in period 2 will be lower than the employment of the first period.

Furthermore, the effective membership is an increasing function of the real wage rate, $\omega_{2}^{c}$, and the average migrating cost $(\bar{\mu} / 2)$, while it is a decreasing function of the rest of the world real wage rate, $\bar{\omega}$, measured in domestic currency units. That is, an increase in the average migration cost will reduce the percentage of migrating insiders. An increase in the real domestic consumer wage, by lowering the wage differential will induce a lower number of insiders to migrate. Finally, an increase in $\bar{\omega}$ due to an increase in $\omega^{f}$ or an increase in $S$, by widening the wage differential, will induce a larger number of insiders to migrate.

The effective union membership can be illustrated in Figure 4 in the $\left(\omega^{p}, L\right)$ space by the upwards sloping line $\mathrm{M} \Lambda$.

We may now turn our analysis to the trade union. How will the union act when it is faced with the possibility that its members may migrate abroad? Given that the union is assumed to care about the welfare of its existing employed members, the kink of the union's indifference curves will occur along its effective membership line $M \Lambda$. That is, the union's indifference curves will be horizontal to the right of the membership line $\mathrm{M} \Lambda$ and downwards sloping to the left of it. Furthermore, since we are to the right of the demand curve, the points of tangency between an isoprofit curve and a union's indifference curves are along the $\mathrm{M} \Lambda$ line. That is, in period 2, the effective membership line $\mathrm{M} \Lambda$ is now the new contract curve. Efficient bargains in period 2 are therefore on the $M \Lambda$ line. The particular point of the $M \Lambda$ line that will determine the bargained real wage and the level of employment is given by the intersection of the $M \Lambda$ with the power locus CE. Let $Z$ be the point of intersection. At $Z$ the bargained wage is higher than at $E$, since a movement from $E$ to $Z$, along the downward sloping power locus, represents higher wages and lower employment. Algebraically, point $Z$ is determined by the solution to the equation for effective membership, given by (9), and by the expression for the power locus which is obtained from the maximisation of

$$
\underset{L}{\operatorname{Max}}\left[\frac{L}{M_{2}^{e}}\left[U\left(\omega^{c}\right)-U(\chi)\right]\right]^{\frac{\phi}{1+\phi}}\left[f(L)-\omega_{L}^{p}\right]^{\frac{1}{1+\phi}}
$$

That is,

$$
\omega_{2}^{p}=\frac{\phi}{1+\phi}\left[\frac{\phi f\left(L_{2}\right)}{L_{2}}+f^{\prime}\left(L_{2}\right)\right]
$$


To study the comparative statics we shall make the assumption of a Cobb-Douglas production function i.e.

$$
f(L)=k L^{\alpha}
$$

where $k$ is a constant and $0<\alpha<1$. Substituting (12) into the equation for the power locus and solving for $L_{2}$ we obtain

$$
\begin{aligned}
& L_{2}=b\left(\omega_{2}^{p}\right)^{-\frac{1}{1-\alpha}} \\
& b=\left[\frac{(\alpha+\phi) k}{(1+\phi)}\right]^{\frac{1}{1-\alpha}}>0
\end{aligned}
$$

where

Substituting (13) into the equation for the effective union membership and rearranging we have

$$
b\left(\omega_{2}^{p}\right)^{-\frac{1}{1-\alpha}}-L_{1}^{*}\left[1-\frac{\bar{\omega}-\omega_{2}^{c}}{\bar{\mu}}\right]=0
$$

Proposition 1: The home real product wage as well as the home real consumption wage will be higher under conditions of international migration than without international migration.

This is because an existing wage differential between the home country and abroad, i.e. $\bar{\omega}>\omega_{2}^{c}$ will create a migration outflow of workers and will therefore reduce the number of remaining insiders and thus the number of jobs to be protected by the union ${ }^{14}$. Since the behaviour of the union is determined by the behaviour of insiders who are also assumed to be able to know the migration outflow of the union members, the union will bargain for a real wage so that all of its remaining members will be employed i.e. $M_{2}^{e}=L_{2}<L_{1}^{*}$. Given the negative relationship between employment and real product wages, reflected in the power locus, the union will achieve a higher real product wage $\omega_{2}^{p}$ than that achieved in the absence of international migration, i.e. $\omega_{2}^{p}>\omega_{1}^{p}$. This also implies a higher real consumption wage in period 2, i.e. $\omega_{2}^{c}>\omega_{1}^{c}$, for any given real exchange rate ${ }^{15}$. Therefore, using the

\footnotetext{
${ }^{14}$ As Ghosh (1996), p.90 notes "empirical evidence in several labour-sending countries confirms the negative consequences of labour outflows on employment".

15 This result is in line with Hazari (1994) who finds that outmigration results in an increase in the reward of the remaining potential migrants. For empirical evidence see Ghosh (1996), Ghatak (1996), Boyer (1993), and
} 
assumption of risk neutrality, we may write $\omega_{2}^{c}>\omega_{1}^{c}=[\psi /(\psi-1)] \chi$, where $\psi=(\phi+\alpha) / \phi(1-\alpha)$

Proposition 2: Real product and real consumption wages in period 2 are inversely related to membership in period 1.

From (14) we have

$$
\frac{d \omega_{2}^{p}}{d L_{1}^{*}}=\frac{\left(\omega_{2}^{p}\right)^{(1+\sigma)} S^{(1-\lambda)}\left(\bar{\omega}-\omega_{2}^{c}-\bar{\mu}\right)}{b \bar{\mu} \sigma S^{(1-\lambda)}+L_{1}^{*}\left(\omega_{2}^{p}\right)^{(1+\sigma)}}<0 \quad \text { and } \quad \frac{d \omega_{2}^{c}}{d L_{1}^{*}}=\frac{\left(\omega_{2}^{p}\right)^{(1+\sigma)}\left(\bar{\omega}-\omega_{2}^{c}-\bar{\mu}\right)}{b \bar{\mu} \sigma S^{(1-\lambda)}+L_{1}^{*}\left(\omega_{2}^{p}\right)^{(1+\sigma)}}<0
$$

where $\sigma=1 /(1-\alpha)$ and $\bar{\omega}-\omega_{2}^{c}<\bar{\mu}$.

That is, for any given wage differential between the home country and abroad, higher union membership in period 1 will result in higher effective membership in period 2. Since effective membership is equal to employment in period 2, the employment level in period 2 will increase. This in turn is possible only through a lower real product wage. Therefore, higher membership in period 1 will be associated with a lower real consumption wage in period 2.

Proposition 3: An increase in the average migration cost will reduce the home real consumption wage:

$$
\frac{d \omega_{2}^{p}}{d \bar{\mu}}=-\frac{\left(\bar{\omega}-\omega_{2}^{c}\right) L_{1}^{*} S^{(1-\lambda)}\left(\omega_{2}^{p}\right)^{(1+\sigma)}}{\bar{\mu}\left[b \bar{\mu} \sigma S^{(1-\lambda)}+L_{1}^{*}\left(\omega_{2}^{p}\right)^{(1+\sigma)}\right]}<0 \text { and } \frac{d \omega_{2}^{c}}{d \bar{\mu}}=-\frac{\left(\bar{\omega}-\omega_{2}^{c}\right) L_{1}^{*}\left(\omega_{2}^{p}\right)^{(1+\sigma)}}{\bar{\mu}\left[b \bar{\mu} \sigma S^{(1-\lambda)}+L_{1}^{*}\left(\omega_{2}^{p}\right)^{(1+\sigma)}\right]}<0
$$

That is, an increase in the average migration cost, by reducing the percentage of insiders who are potential migrants at any given wage differential between home and abroad, will result in a higher number of non-migrating insiders. Therefore, more jobs should be protected by the union and the bargained real product wage has to be lower at a higher average migration cost. The lower home real product wage will in turn result in a lower home real consumer wage.

Carrington (1996). Ghosh (1996) also records many cases concerning the positive effect of emigration effect on real wages. More specifically, the case of the Republic of Korea in 1975-1980 where wages in the construction sector increased sharply. Similarly, in Pakistan, Thailand and Sri Lanka, since the mid-1970s, wages of workers in occupations affected by migration had risen faster than in other occupations. See also Boyer, Haton and O'Rourke(1993) for similar results concerning the case of Ireland. Indeed, this positive 
Proposition 4: An increase in the rest of the world wage rate measured in foreign currency units will increase both the home real product wage and the home real consumer wage:

$$
\frac{d \omega_{2}^{p}}{d \omega^{f}}=\frac{L_{1}^{*} S\left(\omega_{2}^{p}\right)^{(1+\sigma)}}{b \bar{\mu} \sigma S^{(1-\lambda)}+L_{1}^{*}\left(\omega_{2}^{p}\right)^{(1+\sigma)}}>0 \quad \text { and } \quad \frac{d \omega_{2}^{c}}{d \omega^{f}}=\frac{L_{1}^{*} S^{\lambda}\left(\omega_{2}^{p}\right)^{(1+\sigma)}}{b \bar{\mu} \sigma S^{(1-\lambda)}+L_{1}^{*}\left(\omega_{2}^{p}\right)^{(1+\sigma)}}>0
$$

That is, an increase in $\omega^{f}$, by increasing the existing real wage differential between home and abroad, will induce a larger number of insiders to migrate abroad. Therefore, the remaining insiders, acting through their unions, will be able to increase the real product wage. Moreover, at a given real exchange rate, the increase in the real product wage will increase the home real consumer wage.

Proposition 5: An increase in the real exchange rate, will increase the home real product wage. The sign of the change in the home real consumer wage is ambiguous:

$$
\frac{d \omega_{2}^{p}}{d S}=\frac{L_{1}^{*}\left(\omega_{2}^{p}\right)^{(1+\sigma)}\left[\omega^{f} \lambda S+(1-\lambda) \omega_{2}^{p}\right]}{S\left[b \bar{\mu} \sigma S^{(1-\lambda)}+L_{1}^{*}\left(\omega_{2}^{p}\right)^{(1+\sigma)}\right]}>0 \text { and } \frac{d \omega_{2}^{c}}{d S}=\frac{\left(\omega_{2}^{p}\right)^{(1+\sigma)} L_{1}^{*} \bar{\omega} \sigma(1-\lambda)(\xi-\eta)}{S\left[b \bar{\mu} \sigma S^{(1-\lambda)}+L_{1}^{*}\left(\omega_{2}^{p}\right)^{(1+\sigma)}\right]} \text { ? }
$$

where $\xi=1+\frac{\lambda(1-\alpha)}{(1-\lambda)}>1 \quad$ and $\quad \eta=\frac{\bar{\mu}+\omega_{2}^{c}}{\bar{\omega}}>1$. since $\quad \bar{\omega}<\bar{\mu}+\omega_{2}^{c}$

If $\xi \geq \eta$ then $\left(d \omega_{2}^{c} / d S\right) \geq 0$; otherwise $\left(d \omega_{2}^{c} / d S\right)<0$

That is, an increase in the real exchange rate (depreciation) will increase the existing real wage differential between home and abroad through two channels. First, it will increase the real rest-of-the-world consumer wage in domestic-currency units. Second, it will reduce the home real consumption wage. The increase in the existing real wage differential will induce a larger proportion of insiders to migrate abroad. Therefore, the smaller number of remaining insiders, acting through their union, will succeed in achieving a higher real product wage. In terms of Figure 4, an increase in $S$ will shift the $\mathrm{M} \Lambda$ line leftwards (not shown) along the power locus and will thus lead to a higher real product wage and lower employment in period 2. Moreover, whether or not the increase in real product wage will affect the home real consumption wage depends upon the value of $\xi$ relative to that of $\eta$, which, in turn, depends upon the percentage of potential migrants, the elasticity of the production function with respect to labour and the relative share of home goods in total domestic consumption. 
Proposition 6: A positive shock in the demand for output by strengthening the bargaining position of the trade union will lead to an increase in both the real consumer wage and the employment level.

Following Blanchard \& Fischer (1989), we rewrite the production function as $f(L)=k \theta L^{\alpha}$, where $\theta$ is an improvement in the firm's product market . The positive shock, $\theta$, by increasing both the marginal product of labour and the average product, will shift the power locus upwards along the unchanged membership line and will thus lead to a higher real product wage real consumer wage and employment level. Indeed, equations (13) and (14) remain the same except that the value of $b$ is now given by $b=\widetilde{b} \theta$. Differentiating (14) with respect to $\theta$ and $\omega_{2}^{p}$, one can obtain

$$
\frac{d \omega_{2}^{p}}{d \theta}=\frac{b \bar{\mu} \sigma S^{(1-\lambda)} \theta^{\alpha \sigma}\left(\omega_{2}^{p}\right)^{(1+\sigma)}}{b \bar{\mu} \sigma S^{(1-\lambda)}+L_{1}^{*}\left(\omega_{2}^{p}\right)^{(1+\sigma)}}>0 \text { and } \frac{d \omega_{2}^{c}}{d \theta}=\frac{b \bar{\mu} \sigma \theta^{\alpha \sigma}\left(\omega_{2}^{p}\right)^{(1+\sigma)}}{b \bar{\mu} \sigma S^{(1-\lambda)}+L_{1}^{*}\left(\omega_{2}^{p}\right)^{(1+\sigma)}}>0
$$

also differentiating (13) we have

$$
\frac{d L_{2}}{d \theta}=\frac{b \sigma L_{1}^{*} \theta^{\alpha \sigma}\left(\omega_{2}^{p}\right)^{(1+\sigma)}}{b \bar{\mu} \sigma S^{(1-\lambda)}+L_{1}^{*}\left(\omega_{2}^{p}\right)^{(1+\sigma)}}>0
$$

The relative sizes of these effects on real product wage and employment depend upon the slope of the membership line. Indeed, from equation (9) one may find that the slope of the membership line is $\frac{\bar{\mu} S^{(1-\lambda)}}{L_{1}^{*}}$. The steeper is the slope of the membership line the higher will be the change in the real product wage and the less the size of change in employment, following the positive shock in the product market. Clearly, a very large initial labour $L_{1}^{*} \quad$ force will result relatively small changes in the real product wage while employment will bear most of the brunt of adjustment (Proposition 1).

\section{Conclusions}

In this paper we have incorporated the possibility of international migration of labour into a model of open economy with a non-competitive labour market. Our approach to the 
specification of the labour market is based on a trade union model where employed workers can exercise insider power. The model we have developed allows for a simultaneous determination of union membership, migration flows and real wages. In this framework, we have shown that migration outflows, by reducing the membership of the trade union, lead to a real consumer wage higher than what would have been in the absence of migration. We have also shown that an increase in the rest-of-the-world wage or a decrease in the migration cost, by inducing a larger proportion of insiders to migrate abroad, will lead to higher real consumer wages at home. An increase in the real exchange rate will also increase the home real product wage. However, the sign of change in the home real consumer wage is ambiguous. Finally, an improvement in the firm's product market, by strengthening the bargaining position of the trade union, will raise both the domestic real consumer wage and the employment level. 


\section{REFERENCES}

Agiomirgianakis G.M. (1998), "Monetary-Policy Games and International Migration of Labour in Interdependent Economies", Journal of Macroeconomics, Vol. 20, Number 2, pp.243-266, Spring 1998.

Baldwin R. and Venables A. (1994), "International Migration, Capital Mobility and Transitional Dynamics", Economica, vol. 61, pp. 285-300.

Bhagwati J. and Rodriguez C. (1983), "Welfare-Theoretical Analysis of the Brain Drain", in Bhagwati J. (ed.), Essays in International Economic Theory, Vol. 2, pp.75-102.

Bhagwati J. and Hamada, K. (1974), "Brain Drain, International Integration and Markets for Professional and Unemployment: A Theoretical Analysis", Journal of Development Economics, vol. 1, pp. 19-42.

Blanchard O. and Fischer S. (1989), Lectures on Macroeconomics, Cambridge, Massachusetts, MIT Press.

Blanchard O. and Summers L. (1986), "Hysteresis and the European Unemployment Problem", NBER Macroeconomic Annual, Cambridge, Massachusetts, MIT Press.

Booth A. and Chatterji M. (1993), "Union Membership and Wage Bargaining when Membership is not Compulsory", University of Dundee Discussion Paper, July.

Boyer G. Hatton T. and O'Rourke K. (1993), “The impact of Emigration on Real Wages in Ireland 1850-1914”, CEPR Discussion paper No 854, December.

Brecher R. and Choudhri E. (1987), "International Migration Versus Foreign Investment in the Presence of Unemployment", Journal of International Economics, vol. 23, pp. 329-342.

Burda M. (1993), "The Determinants of East-West German Migration”, European Economic Review, vol. 37, pp. 425-461.

Carlin W. and Soskice D. (1990), Macroeconomics and the Wage Bargain, Oxford, Oxford University Press.

Carrington W. E. Detragiache and T. Vishwanath (1996) "Migration With Endogenous Moving Costs", American Economic Review Vol.86, No 41996.

Carruth A. and Oswald A. (1987), "On Union Preferences and Labour Market Models: Insiders and Outsiders", Economic Journal, vol. 97, pp. 431-445.

Creedy J. and McDonald I. (1991), "Models of Trade Union Behaviour: A Synthesis", Economic Record, vol. 61, pp. 346-359.

Djajic S. (1985), "Minimum Wage, Unemployment and International Migration", Mimeograph, Queen's University Discussion Paper, February.

Drazen A and Gottfries N. (1990), "The Persistence of Unemployment in a Dynamic Insider-Outsider Model", in Weiss Y. and Fischelson G. (eds.), Advances in the Theory and Measurement of Employment.

Fallon P. and D. Very (1988) The Economics of Labour Markets. Phillip Allan

Ghosh B. (1996), "Economic Migration and the Sending Countries" in Van den Broeck J. (ed.), The Economics of Labour Migration, Edward Elgar pp. 77-113.

Ghatak S., Levine P. and Price S W (1996), "Migration theories and Evidence: An Assessment", Journal of Economic Surveys, Vol. 10, No 2.

Gottfries N. and Horn H. (1987), "Wage Formation and the Persistence of Unemployment", Economic Journal, vol. 97, pp. 877-886.

Greenwood M.J. and McDowell J.M. (1986), "The Factor Market Consequences of U.S. Immigration", Journal of Economic Literature, vol. 24, pp. 1738-1772. 
Hazari B. R. (1994), "An Analysis of the Impact of Outmigration on Unemployment, Income and Structural Change". The Journal of International Trade and Economic Development vol. 3 No 2 July, pp. 165-175.

Hicks J.R. (1932), The Theory of Wages, London, Macmillan.

Johnson J. and Salt J. (1990), Labour Migration, David Fulton Publishers.

Layard R., Nickell S. and Jackman R. (1991), Unemployment: Macroeconomic Performance and the Labour Market, Oxford, Oxford University Press.

Layard R., Nickell S. and Jackman, R. (1994), The Unemployment Crisis, Oxford, Oxford University Press.

Lindbeck A. (1993), Unemployment and Macroeconomics, Cambridge, Massachusetts, MIT Press.

Lindbeck A. (1987), "Union Activity, Unemployment Persistent and Wage-Employment Ratchets", European Economic Review, Papers and Proceedings, vol. 31, pp. 157-67.

Lindbeck A. and Snower D. (1986), "Wage Setting Unemployment and Insider-Outsider Relations", American Economic Review Papers and Proceedings, vol. 76, pp. 235-39.

McCulloch R. and Yellen J. (1975), "Consequences of a Tax on the Brain Drain for Unemployment and Income Inequality", Journal of Development Economics, vol. 2, pp. 249-64.

McDonald I. and Solow R. (1981), "Wage Bargaining and Employment", American Economic Review, vol. 71, pp. 891-908.

Molho I. (1986), "Theories of Migration: A Review", Scottish Journal of Political Economy, vol. 33, pp. 396-419.

Nickell S. (1990), "Unemployment: A Survey”, Economic Journal, vol. 100, pp. 391-439.

Rodriguez C. (1976), "Brain Drain and Economic Growth: A Dynamic Model” in Bhagwati J. (ed.), The Brain Drain and Taxation, Amsterdam, North Holland.

Stark O. (1991), The Migration of Labor, Cambridge, Massachusetts, Blackwell.

Schmidt C., A. Stilz and K. Zimmermann (1994), "Mass Migration, Unions and Government Intervention", Journal of Public Economics, Vol. 55, pp. 185-201.

Straubhaar T. and Zimmermann K. (1992), "Towards a European Migration Policy", CEPR Discussion Paper, No. 641.

Tirole J. (1988), The Theory of Industrial Organization, Cambridge, Massachusetts, MIT Press. 